\title{
The intercalated alkali and tholeiitic continental basalts in Hannuoba, China: the episodic magmatic products of distinct mantle sources
}

\author{
ZONGQI ZOU $^{1 *}$, ZAICONG WANG ${ }^{1}$ AND YINUO LIU ${ }^{1}$ \\ ${ }^{1}$ School of Earth Sciences, China University of Geosciences, \\ Wuhan 430074, China; *zouzongqi@,foxmail.com
}

Cenozoic tholeiitic and alkali basalts are widespread in the eastern China $[1,2,3]$, and their petrogenesis could be ascribed to variable mechanisms, e.g., different degrees of mantle melting, distinct source lithologies ${ }^{[2,3]}$, the effect of lithosphere thickness ${ }^{[4]}$, and reaction of the parental magmas with lithospheric mantle during ascent ${ }^{[5]}$. Cenozoic basalts in Hannuoba, North China Craton are renowned for the intercalated tholeiitic and alkali basalts in thick sections of hundreds of meters [1,2,3]. Previous studies suggest their distinct geochemical compositions, irrespective of the eruption sequence ${ }^{[2,3]}$. In order to better understand the origin of Hannuoba basalts and provide insights into the genesis of continental intraplate basalts, we analyzed the major and trace elements, Sr-Nd isotopes and stable Ca isotopes of Hannuoba tholeiitic and alkali basalts.

All alkali basalts from different sections are always characterized by OIB-like trace elements, higher than those of tholeiites, but less enriched $\mathrm{Sr}-\mathrm{Nd}$ isotopes, e.g., ${ }^{87} \mathrm{Sr} /{ }^{86} \mathrm{Sr}=0.70381-0.70443$ vs. $0.70463-0.70487$, supporting the distinct mantle sources for tholeiitic and alkali basalts. However, the chemical makers (e.g., Fe/Mn $>70$ and FC3MS $>0.65)^{[6,7]}$ suggest pyroxenite-bearing sources for both of them. Alkalic basalts show higher $\mathrm{Zr} / \mathrm{Hf}$ (44.0-47.8) but lower $\mathrm{Ti} / \mathrm{Eu}$ and $\delta^{44 / 40} \mathrm{Ca}(0.30-0.62 \%$ o $)$ than those in MORBs (e.g., $0.75-0.86 \%$ for $\delta^{44 / 40} \mathrm{Ca}$ ) ${ }^{[8]}$, which are interpreted to reflect the strong effect of carbonate in source [9]. Instead, the tholeiites display relatively higher $\delta^{44 / 40} \mathrm{Ca}$ (0.56-0.71\%o), but still slightly lower than MORBs. Combined with major elements and $\mathrm{Sr}-\mathrm{Nd}$ isotopes, they more likely reflect tholeiitic basalts as the results of partial melting of pyroxenites, if present, with a subordinate effect of carbonates. A model is proposed to explain the Hannuoba basalts. Melting of carbonated pyroxenites or eclogites and subsequent reaction with peridotites in the asthenosphere produced the source for alkali basalts. The upwelling asthenosphere triggered the melting of the pyroxenitic or hybridized mantle source at the base of metasomatized lithosphere to form tholeiitic basalts. The periodic disturbance and melting may explain the eruption of intercalated tholeiitic and alkalic basalts in Hannuoba.

[1] Fan et al. (1991) JP. 32(4), 765-810. [2] Zhi et al. (1990) CG. 88(1), 1-33. [3] Song et al. (1990) CG. 85, 35-52. [4] Guo et al. (2020) Geology. 48(2), 128-133. [5] Wang et al. (2019) Geology. 46, 771-774.[6] Yang et al. (2016) EarthSCI Rev. 157, 18-31. [7] Herzberg (2011) JP. 52, 113-142. [8] Zhu et al. (2018) JGR: Solid Earth. 123, 1303-1313. [9] Huang et al. (2011) GCA. 75, 4987-4997. 